\title{
前田・山下・松島・渡辺論文に対する論評
}

\section{Comments on Maeda, Yamashita, Matsushima and Watanabe's Paper}

\author{
井 関 弘 太 郎 \\ Hirotaro ISEKI
}

1. 最終氷期最盛時 $(18,000 \pm 3,000$ 年前) の低位海 面から現在に至る CuRray (1965) の Holocene Transgression 飞怙いてはもとより，1969 年に INQUA の 完新世小委員で一応の決定をみた完新世（約 10,000 年 前以降）に和ける海面上昇量でさ光，40５0 m に達す るものと推則されている。このことからみて, 縄文草創 期を含さ縄文時代の遺跡が，少なからず，現在の海水準 面下に水没または埋没しているであららことは，これま でにも考觉られていた。 しかし埋没深度の関係もあっ て，との事実を確認するまで恎っていなかったが， このたびの愛知県美浜町の先䒵貝塚の発見は, 遺跡の直 接的な発掘ではなかったにしても, 多数の試錐資料から 遺跡の埋没状況をかなり的確に解明し，あわせて当時の 海面との関係を推定できたことは, 東海地方にも縄文早 期高山寺式期の遺跡の所在することが証明されたという 考古学的意義はもとより, 完新世の海面変動をはじめ, 気候環境の復元など，日本の第四紀研究にとって，ひと つの大きな収穫であったと評価することができる。

2. 瀬戸内海中部の児島半島付近の島嶼飞, 縄文早期 押型文土器を伴出するヤマトシジミの貝塚が所在するこ とは，鎌木(1949)，江坂（1954）らにより報告されて和 り, 黄島 (岡山県牛空町) のヤマトシジミ貝塚の ${ }^{14} \mathrm{C}$ 年 代が 8,400土350y. B. P. (M-237) であることは，前田 らの論文にも記されていると特りである。井関 (1957) は，そのようなヤマトシジミ貝塚をむつ島嶼周辺に拈い て，ヤマトシジミの採取を可能にしていた条件を考察し た結果，それらの島嶼周辺の水深 $15 \mathrm{~m}$ 内外に広がる海 底平担面が，汽水性湿地の状態であったことを推定し， 当時，すなわら 8,400 年前ころは，海面が現在より 15 $\mathrm{m}$ 内外低位にあったと考皇た，その後，このことを傍証 するデータが, 名古屋港付近 (井関渒か, 1982), 東京下 町低地 (ENDo et al., 1982) さらに鳥取平野 (豊島, 1978)などから得られてきたが，瀬戸内海の縄文早期貝 塚とほぼ同時期の先苅貝塚の埋没深度，和よび当時の推 定海面からも，そのことが証拠だてられ，8,300〜8,500 年前ころの, 䋥文海進初期の海面高度をかなり正確に復 元できるようになった。

3 . 上記の 2 点のほかに, 同論文の大きなメリットと
して挙げられるのは, 縄文海進高頂期以後の海面の相対 的変動についての実証である. 先苅貝塚付近に所在する 縄文時代前期〜後期遺跡群の下限高度と，含貝海成層や 生痕化石などの海成諸現象の上限高度との間に，それぞ れの時期の海面を推定していった結果, 縄文海進の高頂 期後，4,560 年前ころ (縄文中期) にかけて海面の低下 がみられたが，その後， 3,000 年前ころ（縄文後期）を ピークとする再上昇があったといら変化経過を見いだし ている.このうち縄文中期の小海退については，同論文 でも，太田陽子らが気ついているらしい記述があるが, 縄文後期ころの小海進についての報告には触れていなか った. しかし豊島 (1978) は，山陰海岸の海岸地形と先 史遺跡との研究から， 4,500 年前ころの小海退の後, 4, $000 \sim 3,000$ 年前ころにか忊て小海進のあったことを 報告して括り，その変化経過が先苅貝塚付近の場合に酷 似していることが注意される.

このような海面変化の経過は，前田らの論文に和ける 4,500 年前ころの小海退が，Fairbridge 曲線の Baha-

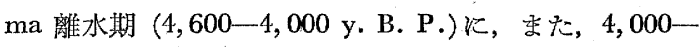
3,000 年前のころの小海進が, Younger Peron 沈水期 (4,000-3,400 y. B. P.) 飞かなり近似した現象である ことに気づくのである. あっとも，そのことによって， Fairbridge 曲線が全面的に日本の完新世の海面変 化経 過に当てはまるといらのではないが，研究が蓄積される のにしたがって，日本のそれが Fairbridge 曲線に近づ く傾向にあることは否定できないようである。

上述のような大きなメりットに比べて些細なことであ るが，次のような諸点について配慮がいただきたかった と思っている.

まず，(1)先苅貝塚が位置している基盤(第三系中新統) の地形を「埋没波食台」としているが，そ水が波食台で あったという説明がみられない，成因が不明な場合は， 地形分類用語を用いない方が良いのではないか.

(2)「先获具塚のハイガイの ${ }^{14} \mathrm{C}$ 年代值は $8,330 \pm 260$ y. B. P. (Gak-7950)」と記述しているのに対して, 「4. 古内湾の海況変遷」の個所では, 「先苅貝塚は 8,200 年前後に……波食台上に形成されたものと考完られる」 としてあるのは, やや統一性に欠ける。 
(3)「穿孔貝の生痕」がみられる「波食崖の高度は 4.5 $\mathrm{m}\rfloor$ とあるか, この場合は, 生痕の上限高度が海抜 4.5 $\mathrm{m}$ であるの意と解するが，その点を明記されたい、ま た, その生痕が「縄文海進の高海面期に形成された可能 性」があるとしていることについても，もらすこし詳し く説明してほしかった。

このような点についての検討を今後に期待するにして も，先にあげた当論文の大きなメリットを減殺するもの ではない。これが日本の第四紀研究にとって，ひとつの 重要な研究業績として永く評価されるであろうことは疑 えない。

\section{引用文献}

Gurray, J. R. (1965) Late Quaternary history, continental Shelves of the United States. WRICHT, H. E., et al. (eds.), The Quaternary of the United States : Princeton, Princeton University Press, p. 723 -735 .

完新世に乱いて海面はユースタティックにはどのよう に変化してきたかという問題に関して，次の二点につい て異なった見解がある。一つは海面は小変動したのか, 平滑に上昇したのかといら点で，いま一つは高海面期は 過去に存在したか，したとするならばその高さはどの程 度かという点である.この論文ではこれらの問題を考学 る上でいくつかの重要な指摘がなされている.ここでは この二点にかかわる問題についてコメントを述べる.

(1)この論文では縄文中期に海面の小低下があったこと が述べられている. この時期の小低下については，太田 ほか (1982) によって日本各地の海面変化曲線の比較か ら，それが局地的なるのではなく，少なくとも沉日本的 な現象である可能性の強いことが指摘されている. 乙か し以前から度々指摘されてきた弥生期ごろの海面の小低 下が，日本に扣いて 20 カ所あまりの地域で認められて いるのに対し, 縄文中期の小低下は数カ所でしか認めら れていなかった。この理由として，2回の小低下が海面 が現海面付近に安定した時期に生じたものであり，しか も低下規模に大きな差がなかったことが挙げられよう。 このために, 䋥文中期の海面の小低下の記録は新しい弥 生の小低下によりしばしば消去され, 検出が困難となっ たものと考えられる。

日本に怙いて縄文中期, 弥生期の 2 回の海面の小低下 が同一地域で認められているところは, 山陰, 房総, 喜 界島, 原町など数カ所である. 房総, 喜界島の例でみら
Endo, K., Sekimoto, K. and Takano, T. (1982) Holocene Stratigraphy and Paleoenvironments in the Kanto Plain, in relation to the Jomon Transgression. Proc. Inst. Nat. Sci., Nihon Univ., no. 17, p. 116.

江坂輝弥 (1954) 海岸線の進退から見た日本の新石器時 代. 科学朝日, 14, no. 3, p. 75-80.

井関弘太郎 (1957) 繩文早期ごろの海面とその相対的変 化. 名古屋大学交学部研究論集, 17, p. 145-163.

井関弘太郎 - 藤井昭二. 藤 則雄 (1982) 名古屋港周辺 資料に基ゔく完新世の海水準変動. 第四紀研究, 21, p. $179-182$.

鎌木義昌 (1949) 備前黄島貝塚の研究. 吉備考古, no. 77 , p. $19-42$.

新潟第四紀研究グループ (1972) 東京低地および新潟平 野沖積層の生層序区分と堆積環境. 地質学論集, no. 7 , p. $213-233$.

豊島吉則 (1978) 山陰海岸における完新世海面変化. 地 理学評論, 51, p. 147-157.

(名古屋大学交学部地理学教室)

$$
\text { 森脇㕕 }
$$

Hiroshi MoRIwakI

れるように, 隆起地域は証拠の欠落の少ない場所で, 完 新世の海面の小変動を検出するのに好条件を備えてい る.

この論文で扱った地域は次の点から考光て 2 回の海面 の小低下を確実なるのとする可能性をるっている．これ までの小変動曲線は, FAIRBRIDGE (1961) 飞代表される ように比較的広い範囲からの海水準資料で描かれたもの が多かった．これは小変動の記録の欠落を補い合うとい ら長所も一方であるが, 異なる地殼変動量をるつ地域か らの資料を使用するといら危険もある。この点, 本地域 のような小範囲の低地では, 得られた旧海水準資料相互 間の地殼変動による地域差を考慮しなくてよい。さらに 本低地は小範囲でありながら様々な海水準指標が分布し ている.この論文での小変動の検出は主に潮間帯に棲息 する貝の化石と貝塚の立地の分析よりなされているが, 他の指標も駆使すれば曲線はさらに確かなるのとなる う. 特にこの低地でもかなりの部分を占めている砂堆は 重要な旧汀線指標である. 砂堆の高さと年代決定を行な う必要があろう。

(2)最高海水準期浲灰したアカホヤ火山灰がこの地域 の海成層より検出されたことが述べられた.アカホヤ火 山灰が日本の完新世海面変化研究にはたす重要な役割の 一つは, 最高海水準の高さの地域的差異を高い精度でと らえることができることである。これまでこのアカホヤ 火山灰は関東以西の海成沖積層中に多数認められてき 
た.しかしそれわの多くは降灰時の海底に堆積したも のであり，旧汀線付近潐積したもの，すなわら降灰時 の海水準の高さが確定されているものは，本論文で指摘 された播磨灘や鹿児島湾北岸などまだ少ない。この論文

縄文文化の遺跡と完新世の海進をはじめて論じた E. S. Morse が 1879 年に「Shell Mounds of Omori」を 世に出した後, 101 年経って 1980 年に, やはり考古学 遺跡からみた縄文海進を論じた報告書『先苅貝塚』が公 けにされた. 埼玉県の寿能泥炭層遺跡と並んで, 先苅貝 塚は，海面変動を直接に確認できる数少ない遺跡の 1 つ である。

第四紀学会の 1982 年大会では “日本考古学々第四紀 研究” のシンポジウムが開催されて, 考古学遺跡の立地 環境などに関する数々の発表と討論が行なわれ，各時代 の考古学遺跡を各埆度から検討するプログラムで, 前田 保夫・山下勝年・松島義章・渡辺 誠の 4 氏による “愛 知県先苅貝塚と縄文海進”といら発表がなされた。 その 内容は, 遺跡の地質, 地形, 微化石, 植物, 動物, 火山 灰などの諸分野に関する学際的な研究成果であったが， 今後の考古学調査の道標となる, 注目すべき発表であっ た.また，その発表を「第四紀研究」にのせ，第 3 者の コメントをそれに付することは，専門家同志の交流を更 に活発することにつながると期待して, 編集委員会によ るこの企画に賛辞を送るものである。

愛知県知多半島の先苅貝塚は海面上昇 (縄文海進) の ために現地表下 15〜16 $\mathrm{m}$ に埋もれた遺跡で，貝塚が築 営された約 8,500 年前から現在にかけて堆積した覆土に は, 海面変動と自然環境に関する多くの情報が含まれて いることは判明された．しかし，先获貝塚の上に約 15 $\mathrm{m}$ の覆土が堆積しているので, 通常の発掘調査は不可 能であり，ボーリング調査に頼らざるを得なかった。 そ のために, 遺跡内の層序に関する細い観察はできなかっ たので, 回収された土器の中に含まれている撚系文土器 は, 貝塚築営当時の高山寺式土器と前後する, 別系統の ものか，あるいは押型文系の高山寺式土器と共伴するが 他の遺跡では，その共伴関係はまだ確認されていないる のであるかについて, 今回の調査で明らかにできなかっ た.

先苅貝塚の調查によって，こうした純粋考古学的な問 題の他に, B. P. 9000 年以降の海面変動に関するいくつ かの問題が提起された．特に，貝塚築営当時の海面の動
で認められたものも水深約 10〜20 $\mathrm{m}$ の海底に堆積した あのとされている. 本地域でも汀線付近に堆積したアカ ホヤ火山灰が検出されることを期待したい。

(東京都立大学理学部地理学教室)

$$
\begin{gathered}
\text { スチュアート・ヘンリ } \\
\text { Henry STEWART }
\end{gathered}
$$

静, 築営後の海面上昇速度, 海面が最高位に達するまで の間に一定の速さで連続的に上昇したのか，あるいは， その間に停滞期をはさんでいたのか，そして，縄文海進 に和ける最高位海水準和よびその年代，といら問題を中 心にしてコメントさせていただくことにしたいと思う。 その他に，それぞれの時代の自然環境復元に関するデー タが豊富に提供されているが，コメンテーターの力不足 のために、それらに関するコメントは他に譲ることにす る.

まず, 貝塚築営当時の海面の動静の問題であるが, 層 序の上部泥層 (UC) 下部に当るところに波食台が認めら れた. この附近では泥岩礫や腐植質が多く, その ${ }^{14} \mathrm{G}$ 年 代は 8,590土230 y. B.P. である. 海面の位置は波食地 形の上限高度に存在していたと考えられるようだが，こ こで形成された波食台は海面上昇の（相対的）停滞期に 相当すると解釈していいだろらか。仮にとのような推定 が許されるものならば, 縄文海進の海面上昇に特ける停 滞期之貝塚形成との相関関係は 1 つの研究課題になる ら。図 5 では海面はほぽ一定の速度で連続的に上昇した ように描かれているが, 有孔虫群集の分析によって示さ れている上昇曲線 (北里, $1980:$ p. 110) は, いくつか の小停滞を示唆している. または, $8,000 \sim 9,000$ 年前の 海面は小変動をしながら停滞ぎみであったとするデータ は仙台平野 (長谷, 1967), 東京湾 (KAIzUKA et al., 1977), 大阪湾 (前田, $1977 \cdot 1980)$, 九州の荒戸 (下山 ほか，1978）と有明海（有明海研究グループ，1965）に も示されている.

先苅貝塚が築営されたのち，海面は急速に上昇したよ らであるが, 先苅貝塚のデータを含めて, 他の研究成果 によっても, 海面が現在の海水準と同じ高さに達するま で，その上昇は活注一定の速度で連続的であったようで ある.つまり, 別の言い方にすれば, 高山寺式土器の時 代から早期末までの間に海水面はどんどん上がり，停滞 期はなかったようである. 先苅貝塚のデータによって提 示されている 6,000 y. B. P. の+4.5 5.5 m の最高 位海水準は, 他の研究に照合（スチュアート, 1982 : p. 138)すると，その高度がやや高すぎる感じがする，乙か 
し，先苅貝塚附近では，現在，少し隆起する傾向が認め られているよらであるので, 綶文海進の時代に沈降する 証拠が示されない限り, $+4.5 \mathrm{~m}$ 以上の高位海水準が存 在したと考えるべきであろら。または，6,000 年前の高 海面期は，埼玉県の寿能泥炭層遺跡で確認された関山・ 黒浜式土器期の高海面時期とほぼ一致するものである.

かねてから，貝塚が形成される時期と海面変動との関 係について考えているが，先苅貝塚の研究成果を読んで みると, 最高位に達するまでの海面の上昇期に竹ける停 滞，もしくは一時的な小降下の時期こそ，貝塚が形成さ れる時期と一致するものであるとの確信を深めた。ちな みに, 貝塚形成期と, 先苅で推定される約 8,500 年前の 停滞期との一致は他の地方にも見られるであろらか。資 料はやや古いが，手元にある千葉県の遺跡地名表（伊藤 汪か，1959）によると，千葉県では 300 余の貝塚が確 認されているが，そのうら，先苅貝塚の高山式土器と ほぼ同じ時期の田戸式土器を産する貝塚は 10 力所あ り，海面の停滞・小降下があったと推定される 9,000〜 8,000 年の間に該当する貝塚を数えてみると，その数は 20 力所余である. しかし，一方では，田戸式から早期末 の茅山式までの時期には，千葉県沿岸での貝塚の発見例 は皆無に等しい，として早期末の茅山式から前期前葉の 関山・黑浜式の時期にかけて，貝塚の数は急增して，50 カ所にのぼる.

または，先苅の近く，海面が最高位に達したとほぽ同 じ時期に, 清水ノ上と呼ばれる, 早期末から営まれた遺 跡がある. 先苅貝塚の築営期から, 清水ノ上遺跡が形成 されるまでの間に貝塚が営まれていないことが確認され ると，千葉県の情況を考光合わせれば，約 8,500 年前か らの縄文海進の上昇期に和いて，貝塚は形成されなかっ た可能性が出てくる，つまり，貝塚の形成時期と海面の 動静との関係が仮定されるのである.

前田等の報告では, 縄文海進は約 9,000 年前に 開始 したと記されているが，海進の開始年代はなぜ 9,000 年 B. P.とされているのであろうか. 確かに多くの研究 者は B. P. 9, 000 8,000 年間は縄文海進の開始年代て あるとしているが，なぜその年代を開始年としているの か，宾聞にしてその理由つけは知らない，その頃に海面 は停滞期から上昇期に転じたことと関係しているのであ ろう. しかし，縄文文化が出現する B. P. 12,000 年前 にもはっきりした停滞海水準位は確認されている(大嶋, 1980・1982）ので，縄文海進の“縄文”を重視するな ら，むしろ縄文文化が発生する完新世以降，弥生文化
での海面上昇現象を全体的に縄文海進と名づけるべきで はなからうか。 とれで，完新世以降の海水面上昇過程に 括汁るいくつかの停滞期和よび小降下期というイベント に関しては，縄文海進 I，IIなど，というように呼ぶよ らにしたらと思う。すなわち, 約 12,000 年前に成立し た縄文文化以降，弥生文化が成立する約 2,300 年前ま での海水面上昇現象を縄文海進と呼び，B. P. 12,000 8,000 年間は縄文海進 I，B. P. 8, 500 6, 000 年間は縄 文海進 II, B. P. $6,000 \sim 3,000$ 年間は縄文海進 III という 区分を提晿してみたい。ここで，紙幅に制限があるの で, 詳しい考察を別の機会に譲る.

先苅貝塚で確認された海面変動とその年代と, 土器編 年との関係に関連して，山内清男によって提唱された縄 文文化年代観は成立しないことについては，すでに論考 した（スチュアート，1982：p. 136）ので，ここで詳述 しない.

\section{引用交献}

有明海研究グループ(1965) 有明・不知炎海域の第四系. 地団研専報, no. 11，86p.

長谷弘太郎 (1967) 宮城県沖積平野の地質学的研究. 東 北大学地質・古生物研究室邦交報告, no. 64, p. 1 45.

伊藤和夫 · 金子浩昌 (1959) 千葉県石器時代遺跡地名表. 144p., 房総考古学会.

海津正倫 (1979) 更新世末期以降における濃尾平野の地 形発達過程. 地理学評論, 52, p. 199-208.

Kaizuka, S., Naruse, Y. and Matsuda, I. (1977) Recent Formations and their Basal Topography in and around Tokyo Bay, Central Japan. Quaternary Research, 8, p. 32 50.

北里 洋 (1980) 有孔虫群集からみた内海の環境変遷. 山下勝年編 「先苅貝塚」愛知県知多郡南知多町, $\mathrm{p}$. 106-112.

桑原 徹 - 吉野道彦・高田康秀（1972）伊勢湾と周辺地 域の埋没地形々第四系 “沖積層” 細分. 地質学論集, no. 7 , p. $61-76$.

前田保夫 (1980) 臨海平野の表層部に残る繩交海進の記 録. 月刊地球, 13, p. 40-45.

前田保夫（1977）大阪湾の自然史. 科学，47, p. 514 523.

大鷝和雄 (1980) 海峡地形に記された海水準变動の記録. 第四紀研究, 19, p. 23-38.

大嶋和雄 (1982) 最終氷期の最低位海水準について. 第 四紀研究， 21， p. 211-222.

下山正一一首藤次男 (1978) 福岡市荒户の第四紀層の貝 化石集団について. 九州大学理学部研究報告, 13-1, 地質学, p. 47- 59 .

(早稲田大学交学部考古学教室) 


\section{太田陽子 \\ Yoko OTA}

本論文は，日本で始めて発見された縄文時代早期の海 底埋没貝塚およびそれ以降の貝塚の年代・高度と, 海成 層との関係にもとづいて, 最近約 9,000 年間の環境変遷 と海面変化とを論じた興味深い論文である．本稿では， 特もに海面変化について，二・三のコメントを試みる.

最近 15,000 年間の海面変化は IGCP の Key Project の一つとしてとりあげられ，世界の諸地域で様々な 相対的海面変化曲線がえがかれている（たとえば BLOOM 編，1977). 日本でも数多くの曲線が公にされている(た と党ば OTA et al. eds., 1981 ; 太田ほか, 1982). 海面変 化を考学る際にもっとも問題になるのは，いかにして相 対的海面変化曲線から,さむざまな規模の地殼変動を分 類するかということであるが，それに先立って，上記の 検討にたえらる精度の確実な相対的海面変化曲線を等質 な地域ごとに求めることが要求される. 異なる条件下 の，異なる精度の試料をつなげて曲線をかくという時代 はすでにすぎさったのである．本論文ではその意味では 吟味のゆきどいた第一級の資料を提供しているといっ てよいまた，海成層の上限と，貝塚の下限との間に古 海面を求めようとする基本方針るらなずける. したがっ て, 本地域では䋥文前期の海面高度は海抜 $6 \mathrm{~m}$ をこ党 ることなく, 約 4,500 y. B. P. 以降も 2 2.8 m 以下 であったことは納得できる。

しかし，本論文の相対的海面変化曲線を検討するとい くつかの疑問がでてくる，その第一は，図5に示された 相対的海面変化曲線がもし正しいとすると，それが 2 段 の埋没波食台 (?), 地層の細分, 砂堆列の形成とどう関 係するかといら問題で，これに対する説明は必ずしも十 分に与えられているといい難い，たと艺，上部砂層と 上部泥層と性整合加不整合加，約 6,000 y. B. P. 以降 の海面変化が層序にいかに現われているか，4列の砂堆 の形成要因は何であろらかなどについて疑問が残る.

第二に相対的海面変化曲線自体についての問題であ る. 約 6,000 y. B. P. の海面高度を $+4.5 \sim 5 \mathrm{~m}$ とす る根拠は，海拔 $4.5 \mathrm{~m}$ の生痕化石を縄文前期のものと 推定したことによるが，これを証明する資料はない．お し生痕化石が縄文前期より若いか古いかすると, 上記の 推定は成り立たなくなり，当時の海面はより低くなる 可能性がでてくる.むしろ，図 3 からみると，約 8,500 y. B. P. 以降 3,000 y. B. P. ごろまで海成層の堆積は連 続していたと考觉られる.上部砂層は, 3〜4,000 y.B.P. ごろに海進の速度が和とろえてピークに達するころの環
境を反映しているのではなからうか，約 2,000 y. B. P. 以降の変化については原論文ですでに疑問符がつけられ ているように，本地域には全く資料がないので，破線で あっても描くべきではない，そうすると，約 8,500 y. B. P. 以降海面上昇が進及, 約 4,500 y. B. P. には惊 ぼ現海面に近く, 約 3,000 y. B. P. に最高に達し，そ れ以降海退に転じて現在に至ったといら単純な海面変化 曲線を予想することができる。このような海面変化が考 古遺跡と矛盾するかどうかの検討は当然必要である，縄 文早期の遺跡（図 1 の 1.6）の位置をみると谷奥に近い か，砂堆の背後にある．このよらな場所では海進の進行 中でも泥炭などの埋積により隆化し, 居住の場所になり えた可能性があるうと思われ，上記の推定と大きい矛盾 はないように思うがどうであろうか。

日本列島に和いて，いわゆる縄文海進最盛期以降に海 面の小変動があったことはいくつかの地域で知られてい る. いわゆる弥生海退より以前に, 約 $4,500 \sim 5,000 \mathrm{y}$. B. P. ごろに小進退とその後の小海進があったらしいこ とは, 房総 (横田, 1978), 喜界島 (太田ほか, 1978)な ぞで推定されている．筆者は，一見した時に，図 5 に示 された小海進がそれらに当るのではないかとの印象を受 けた. しかし，上記の 2 地域では海面の相対的小変動を 示す地形・地質上の証拠が残されているのに対し，本地 域では，確実な海面の相対的変化を考えるにはまだ資料 が不足しているように思われる．砂堆列を横切る北東〜 南西方向の測線に沿って，それぞれの地形帯で海成層上 限の高さと年代をより面的に求めるため簡単な掘削調査 をすることによって，上記の疑問のいくつかが解決され ることが期待される.

\section{引用交献}

BLoom, A. L. (1977) Atlas of sea-level curves. $130 \mathrm{p}$. 太田陽子. 町田 洋 ·堀 信行 . 小西健二 · 大村明雄 (1978) 琉球列島喜界島の 完新世海成段丘一完新世海 面変化研究へのアプローチー. 地理評, 51, p. 109130.

Ota, Y., Matsushima, Y. and Moriwaki, H. (1981) Atlas of Holocene sea level records in Japan. $195 \mathrm{p}$.

太田陽子・松島義章・森脇 広 (1982) 日本に打汀る完 新世海面変化に関する研究の現状と問題一Atlas of Holocene Sea-level Records in Japan を資料とし て一. 第四紀研究, 21, p. 133-143.

横田佳世子 (1978) 房総半島南東岸の完新世海岸段丘に ついて. 地理評，51， p. 349-364.

(横浜国立大学教育学部地理学教室) 